\title{
First insights into macro-and meiofaunal colonisation patterns on paired wood/slate substrata at Atlantic deep-sea hydrothermal vents
}

\author{
Daphne Cuvelier $^{\mathrm{a}, \mathrm{b}, *}$, Julie Beesau ${ }^{\mathrm{a}}$, Viatcheslav N. Ivanenko ${ }^{\mathrm{c}}$, Daniela Zeppilli ${ }^{\mathrm{a}}$, \\ Pierre-Marie Sarradin ${ }^{a}$, Jozée Sarrazin ${ }^{a}$
}

\footnotetext{
a IFREMER, Centre de Bretagne, REM/EEP, Laboratoire Environnement Profond, Institut Carnot EDROME, 29280 Plouzané, France

${ }^{\mathrm{b}}$ IMAR \& Department of Oceanography and Fisheries, University of the Azores, PT- 9901-862 Horta, Portugal

c Department of Invertebrate Zoology, Biological Faculty, Lomonosov Moscow State University, Moscow 119992 , Russia

*: Corresponding author : Daphne Cuvelier, tel.: +330298224755 ; email address : daphne.cuvelier@gmail.com
}

\begin{abstract}
:
In 2006, paired wood and slate panels, each equipped with a temperature probe, were deployed on three different localities on and around the Eiffel Tower edifice (Lucky Strike vent field, Mid-Atlantic Ridge) within close proximity of visible hydrothermal activity. Recovery of these panels took place in 2008. For this two-year deployment period, the composition of colonising organisms (both macro-and meiofauna) was assessed, along with image analyses of the deployment sites in 2006 and 2008. Very few significant differences in colonisation between organic (wood) and inorganic (slate) panels were revealed. Rather, the locality of deployment and the local environmental conditions and hydrothermal activity were found to influence taxonomic composition. Variability in microhabitat conditions and biological interactions were hypothesised to interact jointly in shaping new faunal communities on the colonisation substrata.
\end{abstract}

\section{Highlights}

Colonisation substrata within close proximity of hydrothermal fluid flow. Comparison of colonisation of wood and slate substrata at vents. Community analyses of maco- and meiofaunal composition. Influence of temperature and hydrothermal activity on colonists.

Keywords : Colonisation ; Organic and inorganic substrata ; Mid-Atlantic Ridge ; Hydrothermal ; Recruitment ; Diversity ; Temperature 


\section{$\underline{\text { 1. Introduction }}$}

Hydrothermal vent fields represent hotspots of faunal biomass in the generally lessdensely populated deep-sea environment. Venting areas are characterised by high temperatures (relative to the ambient sea-water at $\sim 2-4^{\circ} \mathrm{C}$ ) and elevated levels of sulphides and other chemical components, such as heavy metals and radionuclides (Sarradin et al., 2009; Charmasson et al., 2009). Hydrothermal vent fauna inhabit steep physico-chemical gradients and are able to survive due to the presence of chemosynthetic microorganisms. These microorganisms use the energy from the oxidation of reduced chemicals (mainly hydrogen sulphides, methane and iron) found in the vent fluids to produce organic matter (Childress and Fisher, 1992; Bennett et al., 2011). They can either be free-living in the vent habitat, or form symbiotic associations with invertebrates. As hot fluid venting is transient, hydrothermal vent sites are considered ephemeral, though vent fields (containing multiple vent sites) have ages ranging from a couple of years (e.g. $9^{\circ} 50^{\prime} \mathrm{N}$ at the East Pacific Rise (EPR, Shank et al., 1998; Lutz et al., 2008) to several decades or even centuries (e.g. MidAtlantic Ridge (MAR) Lucky Strike vent field, Humphris et al., 2002). Despite the degree of isolation and separation between neighbouring hydrothermal vent fields, nascent vent sites in the Pacific were rapidly (from months to a few years) colonised by a pool of regional species, even when the nearest known populated hydrothermal vent was situated kilometres away (Tunnicliffe et al., 1997; Shank et al., 1998; Tsurumi and Tunnicliffe, 2001; Marcus et al., 2009; Mullineaux et al., 2010). Nevertheless, there are large differences in spatial frequency of venting between the ocean ridges; active high-temperature vent fields can be separated by as little as $5 \mathrm{~km}$ on the EPR (Haymon et al., 1991) compared to every $100-350 \mathrm{~km}$ on the MAR (Murton et al., 1994; German et al., 1996).

In order to understand the persistence of the local faunal populations, studies of the temporal variations of faunal abundance and community dynamics at intra- and inter-annual 
scales are fundamental. Since various deep-sea habitats may form a network of suitable environments that contribute to ensure connectivity of deep-sea populations (Génio et al. 2013), the deployment of colonisation substrata can be an effective experiment to better comprehend the colonisation patterns in the deep sea and the possible use of stepping stones, such as organic falls, to colonise new nascent hydrothermal vents. With this purpose, substrata deployment experiments have been carried out in different chemosynthetic settings, using a variety of experimental designs (Van Dover et al., 1988; Mullineaux et al., 1998, 2003; 2012; Shank et al., 1998; Pradillon et al., 2005, 2009; Govenar and Fisher, 2007; Kelly et al., 2007; Kelly and Metaxas, 2008; Gaudron et al., 2010; Bienhold et al., 2013). In all of these studies, variations in settlement and colonisation were mainly influenced by the local environmental conditions (such as temperature and sulphides) and proximity to hydrothermal activity, while biological interactions also played a significant role in community composition. The recruitment of vent-associated species on the colonisation substrata (mostly inorganic) was thought to be influenced by a complex interaction between the composition of the surrounding community (Van Dover et al., 1988), the variability in microhabitat conditions and biological interactions (Mullineaux et al., 2003; Govenar and Fisher, 2007; Kelly et al., 2007; Mullineaux et al., 2012). Gaudron et al. (2010) was the only study that (i) was carried out on the MAR (Rainbow at 2300m depth) and (ii) included the deployment of both organic (wood, alfalfa) and inorganic (carbonate) substrata at hydrothermal vents. However, these experiments were located about $10 \mathrm{~m}$ away from the venting edifice, and therefore beyond the direct influence of the fluids.

The current study is the first to evaluate the composition of macro- and meio-fauna on paired wood and slate panels, equipped with temperature probes and deployed in close proximity $(<20 \mathrm{~cm})$ of hydrothermal venting and within the fluid flow on the MAR. These panels were positioned on and around the Eiffel Tower hydrothermal edifice of the Lucky 
Strike vent field. Wood was chosen due to its organic nature and known occurrence in the deep sea. Sunken woods are widely distributed in the oceans and have been considered as evolutionary stepping stones for hydrothermal vent colonisation (Distel et al., 2000; Bienhold et al., 2013). This is because their decomposition eventually leads to the production of hydrogen sulphide, which attracts chemosynthetic life. Although there are no formal records of wood falls south of the Azores, it is likely that these are present in the deep Atlantic Ocean (e.g. sunken vessels). Slate was chosen as a settlement substrate because it is smooth, inert and resembles basalt. It is therefore a good proxy for the surrounding deep-sea floor at the basalt-hosted Lucky Strike site.

The main hypotheses tested were the following: (a) there is a difference in colonisation between organic and inorganic substrata, (b) environmental conditions and proximity of hydrothermal venting influence the composition and abundance of colonists. This study will provide information about the composition of the species pool at the Lucky Strike vent field and on the environmental heterogeneity within this area, as well as allowing us to compare the habitat and fauna of the experimental substrata with those of the surrounding environment.

\section{$\underline{\text { 2. Material \& Methods }}$}

\subsection{Study site}

The Lucky Strike vent field is situated at a mean depth of $1700 \mathrm{~m}$ on the Mid-Atlantic Ridge (MAR), south of the Azores. The $11 \mathrm{~m}$ high Eiffel Tower (at $37^{\circ} 17.59 \mathrm{~N}-32^{\circ} 169 \mathrm{~W}$ ) is a well-defined active edifice and is one of the most-visited sites within Lucky Strike (Fig. 1). It has been the focus of numerous ecological studies over the last ten years (e.g. Van Dover et al., 1996; Comtet and Desbruyères, 1998; Desbruyères et al., 2001; Cuvelier et al., 2009; De Busserolles et al., 2009; Cuvelier et al., 2011a; Cuvelier et al. 2012) and a recent long-term temporal variation study (Cuvelier et al.; 2011b). 


\subsection{Experimental design and sample collection}

Two types of substrata, one inorganic (slate as a proxy for basalt, A) and one organic (wood, B), were deployed in pairs (A and B) during the MoMARETO 2006 cruise, on three different localities up and around the Eiffel Tower edifice (Fig. 2), at varying distances to visible hydrothermal activity. Each panel measured $25 \mathrm{~cm}$ long and $20 \mathrm{~cm}$ wide. The thickness of the slate was $1 \mathrm{~cm}$ (adding up to a colonisable surface of $0.109 \mathrm{~m}^{2}$ ). For wood, the thickness was $2.5 \mathrm{~cm}$ making the surface available for colonisation equal to $0.123 \mathrm{~m}^{2}$. Each substratum was equipped with a NKE ST6000 temperature probe, which measured temperature every 5 minutes. Due to dive time constraints, the panels were not replicated.

Substrata A1-B1 and A3-B3 were deployed at the base of the south side of the Eiffel Tower, at $3 \mathrm{~m}$ and 4-5 $\mathrm{m}$ distance from the edifice respectively. Substrata A1 and B1 were placed in the visibly least populated and the least hydrothermally active region. Substrata A3 and B3 were located on a crack with diffuse venting, bordered by Bathymodiolus azoricus mussels and microbial mats. Substrata A2 and B2 were situated on a spur of the Eiffel Tower edifice towards the north-west (Fig. 2). A2-B2 were the only substrata located directly on the edifice and were placed in the most densely populated area of the three deployment sites, within $20 \mathrm{~cm}$ or less of various fluid exits, surrounded by dense B. azoricus assemblages. Two years later, in 2008, these substrata were recovered during the MoMAR08 cruise. All temperature probes continued recording during the entire two-year period, with the exception of the probe attached to substratum A3 for which no temperature data could be recovered (probe failure). Both deployment and recovery of the substrata were carried out with the Remotely Operated Vehicle (ROV) Victor6000. Upon recovery, all substrata were put in a thermally insulated sampling box (one per box) and brought to the surface. When the samples arrived on board, macrofauna $(>250 \mu \mathrm{m})$ was sorted out immediately and separated into taxa. 
The rinse-off of the substrata was put into separate flasks. Samples were fixed in buffered seawater formalin (10\%) and after 48 hours transferred to $70 \%$ ethanol. The substrata panels were fixed in formalin as well, to allow further examination. In the laboratory, all samples were re-analysed in detail and passed over $63 \mu \mathrm{m}$ sieves. Fauna, including the meiofaunal (> $63 \mu \mathrm{m})$ compartment, was identified to the lowest taxonomic level possible using Desbruyères et al. (2006) for the macrofauna. After meiofaunal sorting, nematodes were mounted on slides after formalin-ethanol-glycerol treatment. These were then identified to the species level according to Platt and Warwick (1983, 1988), Warwick et al. (1998), and the recent literature dealing with new nematode genera and species from the Atlantic Ocean (NeMys database, Deprez et al. 2005). Copepod individuals were dissected under a Leica MZ12 microscope and studied with a Leica DMR compound microscope having bright-field and differential interference contrast optics. The nauplii were studied by applying the “hanging drop method” for light microscopy (see Ivanenko et al., 2012).

In contrast to the slate panels, the interior of the wood panels could be colonised. However, wood-boring organisms were only encountered in B1 and B3 (Table 1) and the panels were not degraded or altered. Therefore, we omitted the two wood-boring taxa (Table 1) from the statistical analyses and calculated densities in terms of surface area rather than volume. A colonisation rate index (CI) was calculated by dividing the average number of newly arrived animals/colonists $\left(\right.$ per $\mathrm{m}^{2}$ ) by the number of days the panels stayed at the seafloor (adapted from a recruitment rate index from Romey et al., 1991, Table 1).

\subsection{Image analyses}

Image analysis was used to conduct an assessment of the local environment around the panel sites during both deployment and recovery, adding a temporal component. A surface of $1 \mathrm{~m}^{2}$ surrounding each set of panels was analysed using the free image analysis software 
ImageJ (Rasband et al, 2012). The presence and proximity of visible fluid exits or hydrothermal activity was evaluated. The macrofaunal composition and density were assessed as well as the mussel and microbial coverage. The numbers of dead mussels were counted when possible, but often shattered mussel shells did not allow an accurate estimation of the number of dead individuals. Mussels were considered dead when the nacreous white interior of their shells was visible, implying that they no longer contained body tissues. Presence of mobile animals, such as bythograeid crabs and alvinocaridid shrimps, was noted. This was done for both years, thus showing the natural dynamics of the macrofauna over 2 years at the study site.

\subsection{Statistics}

Taxon densities were Hellinger-transformed prior to multivariate analyses. Hellinger transformation makes community data suitable for linear ordinations (Legendre and Gallagher, 2001). Ordinations (Principal Component Analysis (PCA), Redundancy Analysis (RDA)) and cluster analyses were carried out with the Vegan package (Oksanen et al., 2008) in R (version 2.15.1, R Development Core Team, 2012). Environmental variables, (i.e. mean, minimum, maximum, range and standard deviation of temperature) were subject to the forward selection function from the packfor package in R (Dray et al., 2009), in order to select the variables for the RDA that explained most of the variation in faunal presence and abundance $(\alpha=5 \%)$.

One-way ANOVAs were carried out to test the effect of substratum type (wood and slate) on the overall faunal densities for which panels were thus considered replicates. Additional univariate ANOVAs were carried out on abundant individual species to test the effect of the substratum type, again considering the panels of the same material as replicates. If assumptions of normality and homogeneity were not met, densities were log-transformed. 
Temperature values were analysed with notched boxplots to detect significant differences between the substrata, substratum type (material (A1-A2 vs. B1-B2)) and localisation. Specifically, if the notches surrounding the medians of various boxplots do not overlap in the display, the medians are, roughly, significantly different at about a $95 \%$ confidence level (McGill et al., 1978). Biodiversity indices richness and rarefaction (100) were calculated within the Vegan package. A Kruskal-Wallis test was used to unravel differences in colonisation indices between the substratum types.

\section{Results}

\section{$\underline{\text { 3.1. Faunal composition }}$}

A total of 45 taxa (not counting unidentified larvae, copepodid stages and nauplii), 20 macrofaunal and 25 meiofaunal, was represented on the different panels (Table 1). Of these 45 taxa, 16 were determined to species level (mainly macrofauna), 17 to genus level (mainly Nematoda and Copepoda), 8 to family level (mostly polychaetes, isopods and copepods) and 4 to higher taxonomic levels (nematode phylum, polychaete class, cirriped infra-class, copepod subclass). Overall densities were highest on the panels placed within close proximity of warm water venting and with high densities of surrounding fauna (i.e. locality 2, Tables 1 and 2). Between paired panels of different composition, the wood panels (B) had higher overall densities than the slate panels at each site. (Table 1), although these differences were not significant $\left(\mathrm{R}^{2}=0.1, \mathrm{df}=1, \mathrm{p}>0.05\right)$.

One-way ANOVAs were carried out on the densities of the most abundant species, testing for significant differences between the types of substratum. No significant differences were encountered for these selected macrofaunal taxa. Among meiofaunal taxa, nematodes in the genus Halomonhystera were significantly more abundant on wood than on slate $\left(\mathrm{R}^{2}=0.66\right.$, $\mathrm{df}=1, \mathrm{p}=0.048)$ 
Despite the generally non-significant differences in taxon abundances between the substrata, reflecting the lack of replication and low specimen numbers, some interesting patterns were evident. Two taxa of wood-boring bivalves (Xylophaga atlantica and Pholadoidae indet.) as well as Tisbe spp. copepods were restricted to the wood panels (B, Table 1). However, they were all absent from substratum B2. There were also several unique occurrences or absences among the deployment localities, independent of the substratum. For example, Halacarellus auzendei (Acari) and Obesutanais sigridi (Tanaidacea) were only found in locality 1, while Donsiella $\mathrm{cf}$. bathyalis (Copepoda) were only found at localities 2 and 3, with a higher though non-significant abundance on wood (Table 1). Bathymodiolus azoricus, Lepetodrilus atlanticus and Pseudorimula midatlantica were absent from substratum A3 while Lurifax vitreus displayed its highest abundance on this panel. In contrast, L. vitreus was absent from locality 2. Overall, Gastropoda (Lepodrilus atlanticus, Pseudorimula midatlantica and Protolira valvatoides) were more abundant on the wooden panels, though the differences were not significant. One gastropod species (Lurifax vitreus) was more abundant on the slate panels. The crustaceans Autonoe longicornis and Epicaridae, along with two copepod taxa (undetermined Harpacticoida species and Bathylaophonte cf. azorica) and a nematode in the genus Theristus, were confined to substratum A3. All three amphipod taxa (Bouvierella curtirama, Bonnierella compar, Autonoe longicornis) were absent on the edifice substrata (i.e. locality 2). Cirripeds were scarce and only present on peripheral slate panels (A1, A3). Nematodes in the genera Cephalochaetosoma and Dinetia were both more abundant on the edifice (A2-B2, Table 1). Draconematidae nematodes were generally more abundant than Monhysteridae. Apart from the exceptions mentioned previously, most copepod and nematode taxa showed a somewhat random distribution on the panels. The shrimp Mirocaris fortunata was only present on B2, where it was represented by two individuals. However, while recovering the panels, shrimps were seen swimming around 
and returning to the seafloor surface, indicating that their presence and abundance is underestimated in our data (see section 3.2.).

\subsection{Image analyses between 2006 and 2008}

Images covering an area of $1 \mathrm{~m}^{2}$ around the panel deployment localities were analysed for both years available (2006 and 2008). There was no apparent degradation of the wood panels. Due to the limitations inherent to image analyses, the focus laid primarily on "larger" visible animals, i.e. macrofaunal species (Table 2).

\section{A1-B1}

The visible hydrothermal activity at the A1-B1 deployment site diminished between 2006 and 2008. In addition, the distance of the panels to the nearest fluid exit(s) increased over the two years, showing a relocation of the fluid flow (Table 2). More dead mussels were present in 2008 (their number tripled), along with a $\sim 16 \%$ decrease in microbial cover (Table 2 ). An assemblage of both dead and live mussels was found in a crack with some diffuse flow in 2008 (Fig. 2). The surviving mussels did not appear healthy, i.e. their siphons and shells were open and larger organisms exhibited a very dark periostracum. In 2008, most of the live mussels were found below the substrata panels, closer to the fluid exit identified in 2006 which still showed some faint activity in 2008 . While 2 crabs were present in 2006 , none was observed at this site in 2008. The shrimp densities remained rather constant (Table 2).

\section{A2-B2}

The A2-B2 site was visibly the most active of all deployment locations. There were at least 3 different points of emanating hydrothermal fluid that remained active between 2006 and 2008, bathing the entire site in shimmering water at the times of deployment and recovery. It was 
the only locality that was situated on the actual Eiffel Tower edifice and it also was the most densely populated site. Within the 2-year period, a slight overall increase in microbial cover was observed (Table 2), and both panels were completely covered with filamentous bacteria (Fig. 2). A small increase in mussel coverage was also noticeable, although it was associated with a decrease in mussel densities (Table 2). The same number of crabs was present, whereas a small decrease in shrimp densities was observed.

\section{A3-B3}

A3-B3 was situated the furthest away from the Eiffel Tower edifice. In 2006 and 2008, the locality was characterised by various ledges and cracks with shimmering water, which were inhabited by very small mussels and recruits (Fig. 2). The biggest change noticeable between 2006 and 2008 was the location of panel A3, which had moved about $30 \mathrm{~cm}$ from its deployment locality, to a visibly uncolonised, hydrothermally inactive part of deep-sea floor (Fig. 2). The cause of this displacement/movement is unknown. The microbial cover decreased by $16 \%$ by 2008 (Table 2 ). When investigating the surrounding habitat, a shift of the microbial mats towards the east was noticeable, but this was out of the scope of our image analysis investigation. A decrease of $\sim 3 \%$ in mussel densities was also observed (Table 2). When analysing the video imagery from 2008 , the small $(<1-2 \mathrm{~cm})$ mussels present on top of the ledge in 2006 had disappeared. The mussels had relocated into the crack (under the ledge) and appeared to have grown, i.e. individuals were larger.

\section{$\underline{3.3 \text { Temperature measurements and spatio-temporal dynamics }}$}

All temperature probes, with the exception of A3, recorded temperature measurements for the entire 2-year time span. The mean temperatures were highest on the two edifice substrata (A2: $5.73 \pm 0.31^{\circ} \mathrm{C}$ and B2: $\left.5.52 \pm 0.28{ }^{\circ} \mathrm{C}\right)$. Similarly, the highest maximum 
temperatures were measured on $\mathrm{A} 2\left(7.21^{\circ} \mathrm{C}\right)$, followed by $\mathrm{B} 2$ and $\mathrm{B} 3\left(6.64^{\circ} \mathrm{C}\right.$ and $6.40^{\circ} \mathrm{C}$ respectively). These were also the panels that displayed the broadest standard deviations and temperature ranges (Fig. 3). Panel B3 also had a temperature range $\left(2.07^{\circ} \mathrm{C}\right)$ that was slightly higher than that recorded for B2 $\left(2.02^{\circ} \mathrm{C}\right)$. However, B3's mean temperature value was lower than that of $\mathrm{B} 2\left(4.87\right.$ vs. $\left.5.52^{\circ} \mathrm{C}\right)$. Minimum temperature values of panels $\mathrm{A} 1, \mathrm{~B} 1$ and $\mathrm{B} 3$ fluctuated around surrounding bottom seawater temperature $\left(\sim 4.2^{\circ} \mathrm{C}\right)$. The temperature data recorded were very heterogeneous, ruling out parametric tests. Non-parametrical statistical testing was not facilitated either, as the temperature time-series comprised many data points $(n>200,000)$. To reduce the number of data-points, temperature values were averaged over 24 hours. Significant temperature differences (based on the lack of overlap in the notches around the median) between the panels and the localities of deployment were revealed using boxplots (Fig. 3a and b). No distinct temperature differences between the substratum types were evident (Fig. 3c).

\subsection{Relation with environmental factors}

The PCA carried out on faunal densities showed that, with the exception of A3-B3, the panels/substrata clustered according to the locality rather than to the type of substratum (Fig. 4). The first axis represented $37.5 \%$ of the total variance, visibly corresponding to the separation of the different localities. The second axis, representing $28 \%$ of the variance, coincided with the separation of panel A3. Panels A3 and B3 plotted furthest away from one another thus revealing differences in density and composition. The panels A1-B1 and A2-B2 clustered according to their locality (Fig. 4). Panel B3 showed more affinity with substrata A2 and B2, while A3 plotted more distant to the other panels. The similarities between substratum B3 and A2-B2 were probably due to Bathymodiolus azoricus densities along with high densities of the copepods Smacigastes micheli and Donsiella cf. bathyalis. A2 and B2 
were characterised by the highest abundances of Amathys lutzi. Several copepod and nematode taxa had relatively high densities on various panels, without a distinct preference, and were therefore scattered across the plot, except perhaps for Harpacticoida indet. and to a lesser extent Microlaimus, which appeared more characteristic for A3.

Based on a forward selection procedure, mean temperature and temperature standard deviation were withheld as the most explanatory environmental variables ( $p$-values $<0.05$ ) and incorporated in the calculation of the ordination (RDA, Fig. 5). As there were no temperature data for substratum A3, it was left out of the analysis. The RDA plot explained $80.8 \%$ of the variation in faunal abundance and was significant, in other words it was a significant representation of the relationship between the response and explanatory variables $(\mathrm{F}=4.2$, $\mathrm{df}=2, \mathrm{p}=0.047)$. The first axis was also shown to be significant $(\mathrm{F}=5.16, \mathrm{df}=1, \mathrm{p}=0.028)$, emphasising the importance of the horizontal partitioning created by the plot. Overall, the separation of the substrata between the PCA and the RDA along the horizontal axis was similar but more pronounced in the RDA. The plotting of the taxa was reorganised when the environmental variables were taken into account (Fig. 5). A2 and B2 displayed highest mean temperatures, followed by B3, while all three displayed the largest variations in temperature ranges (represented by the standard deviation). Conversely, A1 and B1 were characterized by lower temperatures and smaller ranges and thus plotted opposite the temperature values (Fig. 5).

\subsection{Diversity and colonisation index}

Richness and rarefaction biodiversity indices were calculated for the faunal abundance data (Table 1). Even though identification was carried out to the lowest taxonomic level possible, not all organisms could be determined to species level. Nevertheless, all taxonomic levels were incorporated in the diversity calculations, even the undetermined species as they 
were considered different from the other identified species. Nauplii, larval and copepodid stages were excluded from these calculations. Overall, at least 45 species were present in the samples, counting each taxon as a "species". This number could represent an underestimation as these higher taxonomic levels (e.g. family, class, etc) could contain more than one species. Substratum B1 was the most taxon rich (31 taxa), followed by A1 and A3 (both with 24 taxa) and B3 (23 taxa) (Table 1). For both indices calculated, A2 and B2 were the least diverse. In general, one index was consistently higher than the other when two panels were compared. The only exception was A3-B3, where taxonomic richness was higher on A3 than on B3, but the order was reversed for the rarefaction (Table 1).

The highest colonisation index (CI, estimated mean number of species arriving per $\mathrm{m}^{2}$ per day, excluding wood-boring bivalves as volume was not taken into account) was found on panel B2 $(\mathrm{CI}=0.84)$, followed by A2 $(\mathrm{CI}=0.81)$ (Table 1$)$. When comparing paired panels, the wood panels (B) featured higher colonisation indices than the slates in the same locality. Noteworthy is that panel A2 also had a higher CI than B1 and B3 (Table 1). Lowest CI's were found on A1 and A3 respectively. Nevertheless, despite these observations, one-way ANOVAs revealed no significant difference between the substratum types for the colonisation index.

\section{Discussion}

This pilot study of a first deployment of paired wood/slate panels in close proximity of hydrothermal flow aimed at evaluating the possible influence of substratum type and environmental conditions on the structure of newly established faunal assemblages, on and around the Eiffel Tower hydrothermal edifice (MAR). The most important experimental limitation was the lack of replicates, urging caution in the interpretation of the results. While there were almost no significant differences in densities of the fauna composition between 
organic (wood) and inorganic (slate) substrata, our results showed the influence of hydrothermal activity (as deduced from temperature measurements) and of the surrounding resident fauna on the composition and diversity of the new assemblages. The present study adds to the small body of literature dealing with early life-history processes on the MAR and provides new information on meiofaunal colonisation at vents.

\section{$\underline{\text { 4.1. Colonists }}$}

Total faunal densities tended to decline with increasing distance from, and diminishing exposure to, hydrothermal activity. Locality 2, on the edifice, featured highest densities, followed by localities 3 and 1, both located in the periphery. The presence of microbial mats on the panels was also limited to locality 2 probably depending on the presence of surrounding microbial mats and the proximity of hydrothermal venting. Independent of the nature of the substratum, filamentous microbial mats were shown to be restricted to active hydrothermal areas, which are essential to fulfil their nutrient and energy requirements (Guezennec et al., 1998, Crépeau et al,. 2011). Most species on the colonisation panels were vent endemics; only two distinct non-vent endemic species were found, i.e. wood-boring bivalves and cirripeds.

\subsubsection{Non-vent endemics}

The presence of wood-boring bivalves in the wooden substrata deployed in the periphery was noteworthy. While present in comparable densities on the wood panels B1 and B3, these bivalves were absent from substratum B2. In general, Xylophaga species are opportunistic and tend to exploit the first food source they encounter (Romey et al., 1994). Their absence in locality 2 , which was most strongly bathed in hydrothermal fluids, could be attributed to the elevated and variable temperatures and corresponding changing chemical 
fluid composition (higher concentrations of sulphides, metals, and low oxygen). Such conditions are likely to limit Xylophaga recruitment and survival, especially as wood-boring bivalves are regular deep-sea species. They are not specifically adapted to the hydrothermal vent environment and have only been recorded near the edge of vent localities (Voight, 2007). Alternatively, the establishment of filamentous microbial cover on the substrata might also have prevented their successful settlement, as wood-boring taxa were shown to have a surface texture preference for settlement and growth (Romey et al., 1994). Similarly, cirripeds were only found at localities 1 and 3 and exclusively on the slate-panels (A). Although there are vent endemic cirriped species, none are known for the MAR (Desbruyères et al,, 2006).

\subsubsection{Vent endemics}

Many of the colonist fauna were recognised as typical for the Eiffel Tower hydrothermal edifice, although some represent new records. Lowest gastropod densities (Lepetodrilus atlanticus, Pseudorimula midatlantica and Protolira valvatoides) were observed on the panels entirely covered by microbial mats (A2-B2). This coincided with the observations of Cuvelier et al. (2011a) at Eiffel Tower, where gastropods were absent in mussel-based assemblages with microbial cover. Even though gastropods at vents are bacterivores, an established filamentous microbial cover could cause difficulties for attachment (complicate settlement) and movement (Cuvelier et al., 2011a). Alternatively, the lower gastropod abundance on A2B2 could be attributed to the larger-sized mussels, which densely surrounded this deployment locality and which could remove gastropod larvae through filtering and thus inhibit settlement (Comtet and Desbruyères, 1998; Lenihan et al., 2008).

On the other hand, L. atlanticus, P. midatlantica limpets and Bathymodiolus azoricus mussels were absent from A3. This could be due to the panel's displacement from its original 
deployment site, to an area with no visible vent fauna or activity. As two other gastropod species (Protolira valvatoides and Lurifax vitreus) were present on A3, it might be that $L$. atlanticus and P. midatlantica have specific nutritional requirements for which they depend on the presence of fluid sources. Lurifax vitreus is also known from cold seeps in the Mediterranean (Olu et al., 2004) suggesting that, although it may depend on reduced chemicals for its survival, it is not necessarily related to the presence of high temperature fluids, explaining its absence from the A2-B2 panels. Protolira valvatoides, on the other hand, is known to be associated with colder vent microhabitats featuring narrower temperature ranges $\left(<1^{\circ} \mathrm{C}\right)$ (De Busserolles et al., 2009; Cuvelier et al., 2011a). Their 'preference' for somewhat colder microhabitats could explain their occurrence on A3. However, we have no temperature data for this panel to confirm this.

The distribution of meiofaunal species could be influenced by the additional hard surfaces provided by the mussel shells. These shells thus contributed to an increasing habitat complexity which, for example, resulted in a unique hydrothermal meiobenthos community in the Snake Pit mussel beds (Zekely et al., 2006). At Lucky Strike's Eiffel Tower, the nematode genera Cephalochaetosoma and Dinetia were more abundant on substrata A2 and B2 (edifice) than on panels from localities 1 and 3 (periphery), revealing an apparent preference for warmer regions. Whether these abundances were effectively linked to the presence of higher hydrothermal fluid inputs remains to be determined. Other factors that could be at play are the proximity of complex mussel assemblages, the high abundance of soft Amathys lutzi tubes (another possible secondary surface), or the presence of a potential source of larvae. The nematode Halomonhystera, a typical deposit feeder, showed a clear preference for wood, indicating a possible link with the sulphide production due to wood decomposition. However, specially-adapted nematode species that harbour symbionts are currently unknown at hydrothermal vents (Vanreusel et al., 2010). 
The majority of the Copepoda identified in this study, especially Dirivultidae, are known only from deep-sea chemosynthetic environments (Ivanenko et al., 2006; Gollner et al., 2011). Exceptions are the families Ameiridae, Ectinosomatidae and Miraciidae, which are more common in non-vent deep-sea benthic communities. This is the first report, however, of Lobopleura cf. expansa at a deep-sea hydrothermal vent. The genus is known from shallow water and was recorded only once before at a depth of $\sim 1000$ m (Gheerardyn et al., 2009). Among the known copepod vent taxa, Smacigastes micheli, previously described for the Lucky Strike vent field, probably feeds on microbial mats and detritus (Ivanenko et al., 2012), which might explain its high densities on panels A2-B2 and possibly on B3. Tisbe spp. were only present on the wood panels. Donsiella cf. bathyalis (Donsiellinae), which belongs to a genus first discovered on sunken woods (Hicks, 1988) and only recently found in chemosynthetic environments, was also more abundant on the wood panels. The same applies for Xylora cf. bathyalis (Donsiellinae) although patterns observed here were not very clear. Van Dover et al. (1998) found numerous foraminifera and folliculinid ciliates on their deployed slate panels, whereas we found none. Whether this was due to our experimental setup or because we did not investigate the panels under a stereo microscope was unclear.

With the exception of gastropod grazers, almost no large mobile organisms $>0.5 \mathrm{~cm}$ were sampled with the substrata panels, while these were visible on the imagery (shrimp, crabs, and pycnogonids). Mirocaris fortunata shrimp were visible on video imagery from all deployment localities, but most abundant in the most hydrothermally active locality 2 . The shrimp distribution on Eiffel Tower was shown to be strongly linked to the presence of hydrothermal activity as they colonised the warmer parts of the vent habitat (Cuvelier et al. 2009, Cuvelier et al. 2011a). Hence, the abundances of mobile species sampled with the panels were probably underestimated. This could be attributed, at least partially, to panel recovery. When recovering the panels, they were picked up with the manipulator arm of the 
ROV and transferred into a sampling box, which allowed the mobile fauna (especially shrimp) to escape from the experimental substrata. As the low numbers of mobile fauna could not be considered representative, the faunal abundances found on the panels did not accurately reflect the entire community structure. In addition, it is more than likely that over time, predation and competition occur on these panels (Mullineaux et al., 2003; Kelly et al. 2007), thus modifying the composition of the community.

\subsubsection{Diversity patterns}

Total taxonomic richness reported in this study (45) was higher than that previously observed in assemblages at the Eiffel Tower (Van Dover and Trask, 2000 (28); Cuvelier et al., 2011a (14)). However, caution is needed since meiofauna was evaluated in the present study, as it was by Van Dover and Trask (2000) (8 taxa) but not by Cuvelier et al (2011a). Even though our identification of hydrothermal vent meiofauna at the Eiffel Tower was often limited to family or genus level, taxonomic richness encountered on the colonisation panels was higher than previously reported. To date, the meiofaunal compartment at deep-sea hydrothermal vents has received much less attention than the larger mega- and macrofaunal compartments (Copley et al., 2007), thus significantly biasing the estimations of diversity (Tsurumi, 2003; Gauthier et al., 2010). In addition, by calculating taxonomic diversity, we combined different taxonomic levels, making this a representation of minimum species richness rather than overall species richness (Gauthier et al., 2010). Indeed, preliminary results of a systematic study of the different assemblages found on Eiffel Tower indicated that up to 29 meiofaunal and at least 40 macrofaunal taxa can be found in these Bathymodiolus azoricus mussel assemblages (Sarrazin et al., unpublished data) compared to 24 meiofaunal taxa and 21 macrofaunal taxa recognised in the present study. 
For both indices calculated, the lowest diversity was found on panels A2 and B2, characterised by warmest and more variable temperatures. Generally, for the paired panels, the wood panel had a higher diversity than the slate panels, although differences were smaller when looking at rarefaction. The exception was the surprising high richness on A3, i.e. higher than $\mathrm{B} 3$, which was due to the presence of several rare taxa, albeit in low abundances (e.g. 1 individual/panel). There were also several unique occurrences of taxa on the panels A1-B1; hence their high diversity. Very few taxa found on the panels originated from the surrounding deep-sea habitat, most of them had known associations with chemosynthetic ecosystems.

\subsection{Influence of substrata}

The composition of the new assemblages was not really affected by the type of material used, except for the presence of wood-boring bivalves, Tisbe copepods and Halomonhystera nematodes which were linked to the wood substratum in particular. The absence of a discernible substratum preference for the majority of the fauna suggested that available "suitable" unoccupied surfaces are scarce at hydrothermal vents and that open spaces are quickly colonised. Like slate, wood is an unnatural surface at vents, although as a result of sulphide production by wood decomposition, this substratum has more affinity to chemosynthetic environments (Distel et al., 2000). Wood could thus influence recruitment and growth of chemosynthetic species, although the time span on the sea-bottom might be too short to allow significant influence of sulphide production. After 1 year at Rainbow hydrothermal vent field (2300m depth, MAR), Gaudron et al. (2010) detected no significant sulphide enrichment on the wooden substrata deployed. Similarly, despite the fact that they were deployed for 2 years, our recovered wood panels were not discoloured, nor were they much degraded. 
When comparing paired panels, the highest faunal densities and CI's were encountered on the wood panels. This is similar to the observations of Gaudron et al. (2010), where organic substrates were more densely colonised than the carbonate (inorganic) ones. The latter study also found polychaetes within the wood, which was not the case in the present study. Lowest densities and CI's were found on the slate panels in the periphery (1 and 3). Van Dover et al. (1998) also found low densities and very few adult specimens on slate-panels that stayed 3 years on the seafloor and attributed this to a combination of competition, migration and predation. Possibly, slate should be reconsidered as a suitable substratum for vent colonisation studies.

\subsection{Influence of environmental cues/temperature}

The temperature measured at each locality showed that locality 2 was indeed the most strongly influenced by hydrothermal inputs, followed by locality 3 and locality 1. Our experimental design revealed high densities and low diversity in the area characterized by high temperature/high fluid inputs (locality 2) and, conversely low faunal densities and high diversity in lower temperatures localities (1 and 3). The combination of high faunal abundance and low taxonomic diversity (locality 2 ), is considered typical for hydrothermal vent ecosystems (Sarrazin and Juniper, 1999; Van Dover and Trask, 2000; Tsurumi, 2003). The high abundance implies higher recruitment in warmer regions or regions characterized by a more vigorous fluid flow (Mullineaux et al., 1998; Metaxas and Kelly, 2010), while the lower diversity suggests that fewer species have the physiological tolerance required to settle, survive and grow in harsher conditions of exposure to higher temperatures, elevated sulphide levels and hypoxia. These observations would thus imply a higher diversity, further away from the fluid exits or with less intense fluid flow (localities 1 and 3), which can be regarded 
as a less stressful environment (Sarrazin and Juniper 1999; Tsurumi, 2003; Cuvelier et al., 2011a).

Highest similarity in faunal composition was observed between A2 and B2 and between $\mathrm{A} 1$ and $\mathrm{B} 1$. The low similarity between $\mathrm{A} 3$ and $\mathrm{B} 3$ was probably due to the fact that panel A3 moved from its original deployment site (next to B3). This highlighted the patchy nature of the hydrothermal vent ecosystems and the steep chemical and thermal gradients colonised by faunal assemblages with different species compositions. Based on the image analyses, the community present at locality A1B1 was considered waning, featuring large dead and live mussels distributed along diffuse venting cracks. Such a large proportion of dead mussels, combined with the remaining surviving mussels lying unstacked, presumably because they no longer produced byssus threads, were considered indicative for waning vent fields (Van Dover, 2002). The temperature data recorded at locality 1 supported this observation as it was characterised by the smallest temperature range and lowest maximum temperatures, although no significant decrease in temperature over time was observed. The low temperature and small ranges could explain the similarity between A3 and A1B1, with the new location of $\mathrm{A} 3$ being an inactive region and locality 1 featuring a senescent assemblage. Locality A2B2, on the other hand, did not change substantially between 2006 and 2008, though the newly available surfaces (colonisation panels) were readily colonised by filamentous microbial mats. Changes were noticeable in mussel densities and distribution, probably due to the redistribution of stacked mussels. In fact, mussel growth could limit space availability and access to fluids, consequently contributing to a decreasing number of individuals.

The observed similarity patterns in species composition thus tended to correspond with the local temperature regimes, showing the importance of temperature in determining species composition. Similar observations were made at $9^{\circ} 50^{\prime} \mathrm{N}$ on the EPR by Mullineaux et 
al. (2012), where the species composition at two different sites, sampled at different times during a post-eruption recolonisation process, clustered according to the local temperature regime. In other deployment experiments at hydrothermal vents, temperature, gradients of hydrothermal flux and species-specific responses to the varying environmental conditions, were shown to influence colonists' abundance (Mullineaux et al., 1998; Shank et al., 1998; Kelly et al., 2007; Pradillon et al., 2009; Mullineaux et al., 2012). However, since temperature is correlated with the concentration of various chemical species such as total dissolved sulphide, iron, methane and oxygen (Le Bris et al., 2006, Kelly et al., 2007; Sarradin et al., 2009, Vuillemin et al., 2009, Cuvelier et al., 2011a), it is difficult to discern the relative influences of temperature and chemistry on faunal distribution. Furthermore, it was hypothesized by Mullineaux et al. (2003) that species interactions tended to vary along the hydrothermal gradient. Zones with high temperatures and high faunal densities exhibiting more inhibiting interactions (e.g. less diverse settlement and incoming migration in an established community) while zones with lower temperatures and lower faunal densities featuring more facilitating interactions (e.g. more diverse settlement). Notwithstanding the low faunal abundances in this study, such a pattern was noticeable within our experimental set-up. Hence, positive and negative biotic interactions could influence colonisation processes, within the constraints of the hydrothermal activity and environment (Van Dover et al., 1988; Mullineaux et al., 2003; Govenar \& Fisher, 2007; Kelly et al., 2007).

\section{Conclusions \& perspectives}

The main limitation of the present study was the lack of replication. While experiments in remote or extreme sites, common in deep-sea ecology, cannot be as robust as those in more accessible locales, the lack of replication required a cautious interpretation of the results. Despite these limitations, this pilot project yielded interesting observations on community 
structure and temperature between the different colonisation substrata on and around the Eiffel Tower edifice. Differences in taxon composition and densities were observed between the wood (organic) and slate (inorganic) panels deployed around Eiffel Tower, although these were only significant for one nematode taxon. Interestingly, very few background (non-vent associated) taxa colonised the new substrata. Whereas the different localities studied here were likely supplied by the same species pool, local environmental variables and the surrounding established resident populations appeared to impact the structure of the new colonist assemblages, which exhibited an increased abundance/decreased taxonomic richness closer to hydrothermal activity. Greater replication in subsequent experiments should be used to test the questions raised by this pilot study.

\section{$\underline{\text { Acknowledgements }}$}

The captains and crews of the N/Os Pourquoi pas? and L'Atalante as well as the pilots of the ROV Victor6000 are warmly acknowledged for their dedicated assistance and for contributing to the success of the MoMARETO and MoMAR08 cruises. The chief scientists of these cruises were Jozée Sarrazin and Pierre-Marie Sarradin for MoMARETO (2006) and Javier Escartin for MoMAR08 (2008). Thanks to Marie Morineaux for verification of the polychaete identifications and to Patrick Briand and Philippe Noël for their help with the experiment. The research of VNI was supported by Ifremer and the Russian Foundation for Basic Research (12-04-01716-a), and the Ministry of Education and Science of the Russian Federation (14.740.11.1049 8334). DZ thanks the EGIDE (France) for the financial support for 3 months internship at Ifremer and the French government through Agence Nationale de la Recherche (ANR) under the "Investissements d'Avenir" programme, reference ANR10-LABX-19-0 for the financial support for 24 months postdoctoral contract. This research project benefited from funds from the ANR DEEP-OASES (ANR06BDV005) and support from the GDR ECCHIS. Thanks to the anonymous reviewers for their thorough reviews and comments which improved the manuscript and to associate editor Andy Gooday for his help in guiding and editing the manuscript. 


\section{References}

Bennett, S.A., Hansman, R.L., Sessions, A.L., Nakamura, K., Edwards, K.J., 2011. Tracing ironfueled microbial carbon production within the hydrothermal plume at the Loihi seamount. Geochim. Cosmochim. Ac. 75(19), 5526-5539.

Bienhold, C., Pop Ristova, P., Wenzhöfer, F., Dittmar, T., Boetius, A., 2013. How Deep-Sea Wood Falls Sustain Chemosynthetic Life. PLoS ONE 8(1): e53590.

Charmasson, S., Sarradin, P.-M., Le Faouder, A., Agarande, M., Loyen, J., Desbruyères, D., 2009. High levels of natural radioactivity in biota from deep-sea hydrothermal vents: a preliminary communication. J. Environ. Radioactiv. 100, 522-526.

Childress, J.J., Fisher, C.R., 1992. The biology of hydrothermal vent animals: physiology, biochemistry, and autotrophic symbioses. Oceanogr. Mar. Biol. Annu. Rev. 30, 337-441.

Comtet, T., Desbruyères, D., 1998. Population structure and recruitment in mytilid bivalves from the Lucky Strike and Menez Gwen hydrothermal vent fields $\left(37^{\circ} 17^{\prime} \mathrm{N}\right.$ and $37^{\circ} 50^{\prime} \mathrm{N}$ on the Mid-Atlantic Ridge). Mar. Ecol. Prog. Ser. 163, 165-177.

Copley, J.T.P, Flint, H.C., Ferrero, T.J., Van Dover, C.L., 2007. Diversity of meiofauna and freeliving nematodes in mussel beds at hydrothermal vents on the northern and southern East Pacific Rise. J. Mar. Biol. Assoc. UK 84, 1141-1152.

Crépeau, V., Cambon Bonavita, M.A., Lesongeur, F., Randrianalivelo, H., Sarradin, P.M., Sarrazin, J., Godfroy, A., 2011. Diversity and function in microbial mats from the Lucky Strike hydrothermal vent field. FEMS Microbiol. Ecol. 76, 524-540.

Cuvelier, D., Sarrazin, J., Colaço, A., Copley, J., Desbruyères, D., Glover, A.G., Tyler, P., Serrão Santos, R., 2009. Distribution and spatial variation of hydrothermal faunal assemblages at Lucky Strike (Mid-Atlantic Ridge) revealed by high-resolution video image analysis. Deep-Sea Res. I 56, 2026-2040

Cuvelier, D., Sarradin, P.-M., Sarrazin, J., Colaço, A., Copley, J.T., Desbruyères, D., Glover, A.G., Serrão Santos, R., Tyler, P.A., 2011a. Hydrothermal faunal assemblages and habitat characterisation at the Eiffel Tower edifice (Lucky Strike, Mid-Atlantic Ridge). Mar. Ecol. Evol. Perspect. 32, 243-255

Cuvelier, D., Sarrazin, J., Colaço, A., Copley, J.T., Glover, A.G., Tyler, P.A., Serrão Santos, R., Desbruyères, D., 2011b. Community dynamics over 14 years at the Eiffel Tower hydrothermal edifice on the Mid-Atlantic Ridge. Limnol. Oceanogr. 56 (5), 1624-1640

Cuvelier D, De Busserolles F, Lavaud R, Floc'h E, Fabri MC, Sarradin PM, Sarrazin J (2012). Biological data extraction from imagery - How far can we go? A case study from the Mid-Atlantic Ridge. Marine Environmental Research 82:15-27; doi:10.1016/j.marenvres.2012.09.001.

De Busserolles, F., Sarrazin, J., Gauthier, O., Gélinas, Y., Fabri, M.C., Sarradin, P.M., Desbruyères, D., 2009. Are spatial variations in the diets of hydrothermal fauna linked to local environmental conditions? Deep-Sea Res. II 56, 1649-1664.

Deprez, T., Steyaert, M., Vanaverbeke, J., Speybroeck, J., Raes, M., Derycke, S., De Smet, G., Ingels, J., Vanreusel, A., Van Gaever, S., Vincx, M., (2005). NeMys. World Wide Web electronic publication. (www.nemys.ugent.be). Department of Marine Biology, Ghent University

Desbruyères D., Biscoito M., Caprais J.C., Colaco A., Comtet T., Crassous P., Fouquet Y., Khripounoff A., Le Bris N., Olu K., Riso R., Sarradin P.M., Segonzac M., Vangriesheim A. (2001). 
Variations in deep-sea hydrothermal vent communities on the Mid-Atlantic Ridge near the Azores plateau. Deep-Sea Res. I 48, 1325-1346.

Desbruyères D., Segonzac M., Bright M., (Eds.) (2006). Handbook of deep-sea hydrothermal vent fauna. Second completely revised edition. Denisia, 18. Biologiezentrum der Oberösterreichischen Landesmuseen. Linz, Austria

Distel, D. L., Baco, A. R., Chuang, E., Morrill, W., Cavanaugh, C. M., Smith, C. R., (2000). Do mussels take wooden steps to deep-sea vents? Nature, 403(6771), 725-6.

Dray, S. with contributions of P. Legendre and G. Blanchet, (2009). packfor: Forward Selection with permutation (Canoco p.46). R package version 0.0-7/r58. http://R-Forge.R-project.org/projects/sedar

Gaudron, S. M., Pradillon, F., Pailleret, M., Duperron, S., Le Bris, N., \& Gaill, F. (2010). Colonization of organic substrates deployed in deep-sea reducing habitats by symbiotic species and associated fauna. Mar. Environ. Res. 70(1), 1-12.

Gauthier, O., Sarrazin, J., Desbruyères, D., 2010. Measure and mis-measure of species diversity in deep-sea chemosynthetic communities. Mar. Ecol. Prog. Ser. 402, 285-302.

Génio L., Warén A., Matos F.L., Cunha M.R. (2013). The snails tale in deep-sea habitats in the Gulf of Cadiz (NE Atlantic). Biogeosciences. 10, 5159-5170.

German C.R., Parson L.M., Bougault F., Coller D., Critchley M., Dapoigny A., Day C., Eardley D., Fearn A., Flewellen C., Kirk R., Klinkhammer G., Landure J.Y., Ludford E., Miranda M., Needham H.D., Patching J., Pearce R., Pelle H., Radford - knoery J., Rouse I., Scott J., Stoffregen P., Taylor P., Teare D., Wynar J. (1996). Hydrothermal exploration near the Azores Triple Junction: Tectonic control of venting at slow - spreading ridges? Earth and Planetary Science Letters 138, 93 - 104.

Gheerardyn H., De Troch M., Vincx M., Vanreusel A. (2009). Harpacticoida (Crustacea: Copepoda) associtaed with cold-water coral substrates in the Porcupine Seabight (NE Atlantic): species composition, diversity and reflections on the origin of the fauna. SCientia Marina 73(4): 747-760.

Gollner S., Ivanenko V.N., Arbizu P.M., Bright M. (2010). Advances in taxonomy, ecology, and biogeography of Dirivultidae (Copepoda) associated with chemosynthetic environments in the deep Sea. PLoS ONE 5(8): e9801.

Govenar B., Fisher C.R. (2007). Experimental evidence of habitat provision by aggregations of Riftia pachyptila at hydrothermal vents on the East Pacific Rise. Mar. Ecol. Evol. Perspect. 28, 3-14.

Guezennec, J., Ortega-Morales, O., Raguenes, G., Geesey, G. (1998). Bacterial colonization of artificial substrate in the vicinity of deep-sea hydrotehrmal vents. FEMS Microbiology Ecology 26. 89-99.

Haymon, R.M., Fornari, D., Edwards, M., Carbotte, S., Wright, D., Macdonald, K.C. (1991). Hydrothermal vent distribution along the East Pacific Rise crest $\left(9^{\circ} 09^{\prime}-54^{\prime} \mathrm{N}\right)$ and its relationship to magmatic and tectonic processes on fast - spreading mid - ocean ridges. Earth Planetary Science Letters 104, 513 - 534.

Hicks, G.R.F. (1988). Systematics of Donsiellinae Lang (Copepoda, Harpacticoida). Journal of Natural History 22: 639-684. 
Humphris, S.E., Fornari, D.J., Scheirer, D.S., German, C.R., Parson L.M. (2002). Geotectonic setting of hydrothermal activity on the summit of Lucky Strike seamount (37 Degrees 17 ' N, Mid-Atlantic Ridge). Geochem. Geophys. Geosyst. 3, doi: 10.1029/2001GC000284

Ivanenko, V.N., Corgosinho, P.H.C., Ferrari, F.D., Sarradin, P.-M., Sarrazin, J., (2012). Microhabitat distribution of Smacigastes micheli (Copepoda: Harpacticoida: Tegastidae) from deep-sea hydrothermal vents at the Mid-Atlantic Ridge, $37^{\circ} \mathrm{N}$ (Lucky Strike), with a morphological description of the nauplius. Mar. Ecol. Evol. Perspect. 33(2): 245-256

Kelly, N., Metaxas, A., 2008. Diversity of invertebrate colonists on simple and complex substrates at hydrothermal vents on the Juan de Fuca Ridge. Aquatic Biol. 3, 271-281.

Kelly, N. E., Metaxas, A., Butterfield, D. A., 2007. Spatial and temporal patterns of colonization by deep-sea hydrothermal vent invertebrates on the Juan de Fuca Ridge, NE Pacific. Aquatic Biol., 1, 1-

Le Bris, N., Govenar, B., Le Gall, C., Fisher, C.R., 2006. Variability of physico-chemical conditions in $9^{\circ} 50^{\prime} \mathrm{N}$ EPR diffuse flow vent habitats. Mar. Chem. 98, 167-182.

Legendre P., Gallagher, E.G., 2001. Ecologically meaningful transformations for ordination of species data. Oecologia 129, 271-280.

Lenihan, H.S., Mills, S.W., Mullineaux, L.S., Peterson, S.H., Fisher, C.R., Micheli, F., 2008. Biotic interactions at hydrothermal vents: Recruitment inhibition by the mussel Bathymodiolus thermophilus. Deep-Sea Res. I 55, 1707-1717.

Lutz, R.A., Shank, T.M., Luther, G.W., Vetriani, C., Tolstoy, M., Nuzzio, D.B., Moore, T.S., Waldhauser, F., Crespo-Medina, M., Chatziefthimiou, A.D., Annis, E.R., Reed, A.J., (2008). Interrelationships between vent fluid chemistry, temperature, seismic activity, and biological community structure at a mussel-dominated, deep-sea hydrothermal vent along the East Pacific Rise. J. Shellfish Res. 27, 177-190.

Marcus, J., Tunnicliffe, V., Butterfield, D., (2009). Post-eruption succession of macrofaunal communities at diffuse flow hydrothermal vents on Axial Volcano, Juan de Fuca Ridge, Northeast Pacific. Deep-Sea Res. II 56, 1586-1598.

McGill, Robert; Tukey, John W.; Larsen, Wayne A. (1978). "Variations of Box Plots". The American Statistician 32 (1): 12-16.

Metaxas, A., Kelly, N.E., 2010. Do Larval Supply and Recruitment Vary among Chemosynthetic Environments of the Deep Sea? PLoS ONE 5(7): e11646.

Mullineaux, L.S., Mills, S.W., Goldman, E., 1998. Recruitment variation during a pilot colonization study of hydrothermal vents (950’N, East Pacific Rise). Deep-Sea Res. II 45, 441-464.

Mullineaux, L.S., Peterson, C.H., Micheli, F., Mills, S.W., 2003. Successional mechanism varies along a gradient in hydrothermal fluid flux at deep-sea vents. Ecol. Monogr. 73, 523-542.

Mullineaux, L.S., Adams, D.K., Mills, S.W, Beaulieu S.E. (2010). Larvae from afar colonize deep-sea hydrothermal vents after a catastrophic eruption. Proceedings of the National Academy of Science 107, 7829-7834.

Mullineaux, L.S., Le Bris, N., Mills, S.W., Henri, P., Bayer, S.K., Secrist, R.G., Nam, S., 2012. Detecting the influence of initial pioneers on succession at deep-sea vents. PLoS ONE 7(12): e50015. 
Murton B.J., Klinkhammer G., Becker K., Briais A., Edge D., Hayward N., Millard N., Mitchell I., Rouse I., Rudnick M., Sayanagi K., Sloan H., Parson L. (1994). Direct evidence for the distribution and occurrence of hydrothermal activity between $27^{\circ}-30^{\circ} \mathrm{N}$ on the Mid - Atlantic Ridge. Earth Planet Science Letters 125, 119 - 128.

Oksanen, J., Kindt, R., Legendre, P., O’Hara, B., Simpson, G.L., Solymos, P., Stevens, M.H.M., Wagner, H., 2008. vegan: Community ecology package. R package version1.15-0. http://cran.rproject.org/S, http://vegan.r-forge.r-project.org/.

Olu-Le Roy, K., Sibuet, M., Fiala-Medioni, A., Gofas, S., Salas, C., Mariotti, A., Foucher, J.P., Woodside, J., 2004. Cold seep communities in the deep eastern Mediterranean Sea: composition, symbiosis and spatial distribution on mud volcanoes. Deep-Sea Res. II 51, 1915-1936

Platt, H.M. Warwick, R.M., 1983. A synopsis of the freeliving marine nematodes. Part I: British Enoplids. Cambridge University Press, Cambridge.

Platt, H.M. Warwick, R.M., 1988. A synopsis of the freeliving marine nematodes. Part II: British Chromadorids. Cambridge University Press, Cambridge.

Pradillon, F., Zbinden, M., Mullineaux, L.S., Gaill, F., 2005. Colonisation of newly-opened habitat by a pioneer species, Alvinella pompejana (Polychaeta: Alvinellidae), at East Pacific Rise vent sites. Mar. Ecol. Prog. Ser. 302, 147-157.

Pradillon, F., Zbinden, M., Le Bris, N., Hourdez, S., Barnay, A.-S., Gaill, F. 2009. Development of assemblages associated with alvinellid colonies on the walls of high-temperature vents at the East Pacific Rise. Deep-Sea Res. II 56, 1622-1631

Rasband, W.S., 2012. ImageJ, U. S. National Institutes of Health, Bethesda, Maryland, USA, http://imagej.nih.gov/ij/, 1997-2012.

Romey, W.L., Castro, K.M., Dealteris, J.T., Bullock, R.C., 1991. Recruitement in the deep-sea woodboring bivalve Xylophaga atlantica Richards. The Veliger 34(1), 14-20

Romey, W.L., Bullock, R.C., Dealteris, J.T., 1994. Rapid growth of a deep-sea wood-boring bivalve. Cont. Shelf Res. 14 (12), 1349-1359

Sarradin, P.M., Caprais, J.C., Riso, R., Kerouel, R., Aminot, A., 1999. Chemical environment of the hydrothermal mussel communities in the Lucky Strike and Menez Gwen vent fields, Mid Atlantic Ridge. Cah. Biol. Mar. 40, 93-104.

Sarradin, P.M., Waeles, M., Bernagout, S., Le Gall, C., Sarrazin, J., Riso, R., 2009. Speciation of dissolved copper within an active hydrothermal edifice on the Lucky Strike vent field (MAR, $\left.37^{\circ} \mathrm{N}\right)$. Sci. Total Environ. 407, 869-878.

Sarrazin, J., Juniper, S.K., 1999. Biological characteristics of a hydrothermal edifice mosaic community. Mar. Ecol. Prog. Ser. 185, 1-19.

Shank, T.M., Fornari, D.J., Von Damm, K.L., Lilley, M.D., Haymon, R.M., Lutz, R.A., 1998. Temporal and spatial patterns of biological community development at nascent deep-sea hydrothermal vent ( $9^{\circ} 50^{\prime} \mathrm{N}$, East Pacific Rise). Deep-Sea Res. II 45, 465-515.

Tsurumi, M., Tunnicliffe, V., 2001. Characteristics of a hydrothermal vent assemblage on a volcanically active segment of Juan de Fuca Ridge, Northeast Pacific. Can. J. Fish. Aquat. Sci. 58, 530-542. 
Tsurumi, M., 2003. Diversity at hydrothermal vents. Global Ecol. and Biogeogr. 12, 181-190.

Tunnicliffe, V., Embley, R.W., Holden, J.F., Butterfield, D.A., Massoth, G.J., Juniper, S.K., 1997. Biological colonization of new hydrothermal vents following an eruption on Juan De Fuca Ridge. Deep-Sea Res. II 44, 1627-1644.

Van Dover, C.L., Berg, C.J., Turner, R.D., 1988. Recruitment of marine invertebrates to hard substrates at deep-sea hydrothermal vents on the East Pacific Rise and Galapagos spreading center. Deep-Sea Res. 35, 1833-1849.

Van Dover, C.L., Desbruyères, D., Segonzac, M., Comtet, T., Saldanha, L., Fiala-Medioni, A., Langmuir, C. (1996). Biology of the Lucky Strike hydrothermal field. Deep-Sea Res. I 43, 1509-1529.

Van Dover, C.L., Trask, J.L., 2000. Diversity at deep-sea hydrothermal vent and intertidal mussel beds. Mar. Ecol. Prog. Ser. 195, 169-178.

Van Dover, C. 2002. Community structure of mussel beds at deep-sea hydrothermal vents. Mar. Ecol. Prog. Ser. 230, 137-158.

Vanreusel, A., De Groote, A., Gollner S., Bright, M., 2010. Ecology and biogeography of free-living nematodes associated with chemosynthetic environments in the deep sea: A review. PLoS ONE 5(8): e12449.

Voight, J.R., 2007. Experimental deep-sea deployments reveal diverse Northeast Pacific woodbooring bivalves of Xylophagainae (Myoida: Pholadidae). J. Molluscan Stud. 73, 377-391.

Vuillemin, R., Le Roux, D., Dorval, P., Bucas, K., Sudreau, J.P., Hamon, M., Le Gall, C., Sarradin, P.M., 2009. CHEMINI: a new in situ CHEmical MINIaturized analyzer. Deep-Sea Res. I 56, 13191399.

Warwick, R.M., Howard, H.M., Somerfield, P.J., 1998. A synopsis of the freeliving marine nematodes. Part III: Monhysterids. Field Studies Council, Shrewsbury.

Zekely, J., Van Dover, C.L., Nemeschkal, H., Bright, M., 2006. Hydrothermal vent meiobenthos associated with mytilid mussel aggregations from the Mid-Atlantic Ridge and the East Pacific Rise. Deep-Sea Res. I 53, 1363-1378. 


\section{$\underline{\text { TABLES }}$}

Table 1. Taxonomic composition. density and richness of the slate and wood panels deployed for two years in the vicinity of the Eiffel Tower edifice (Lucky Strike. MAR). The substrata deployed directly on the edifice are marked with an E while those in the periphery are marked with a P. A colonisation index was calculated by dividing the average number of new recruits $\left(\right.$ per $\mathrm{m}^{2}$ ) by the number of days the panels stayed at the sea bottom. Grey rows feature raw abundances instead of densities. Larvae, nauplii and copepodids were not included in the taxonomic richness or in other diversity indices.

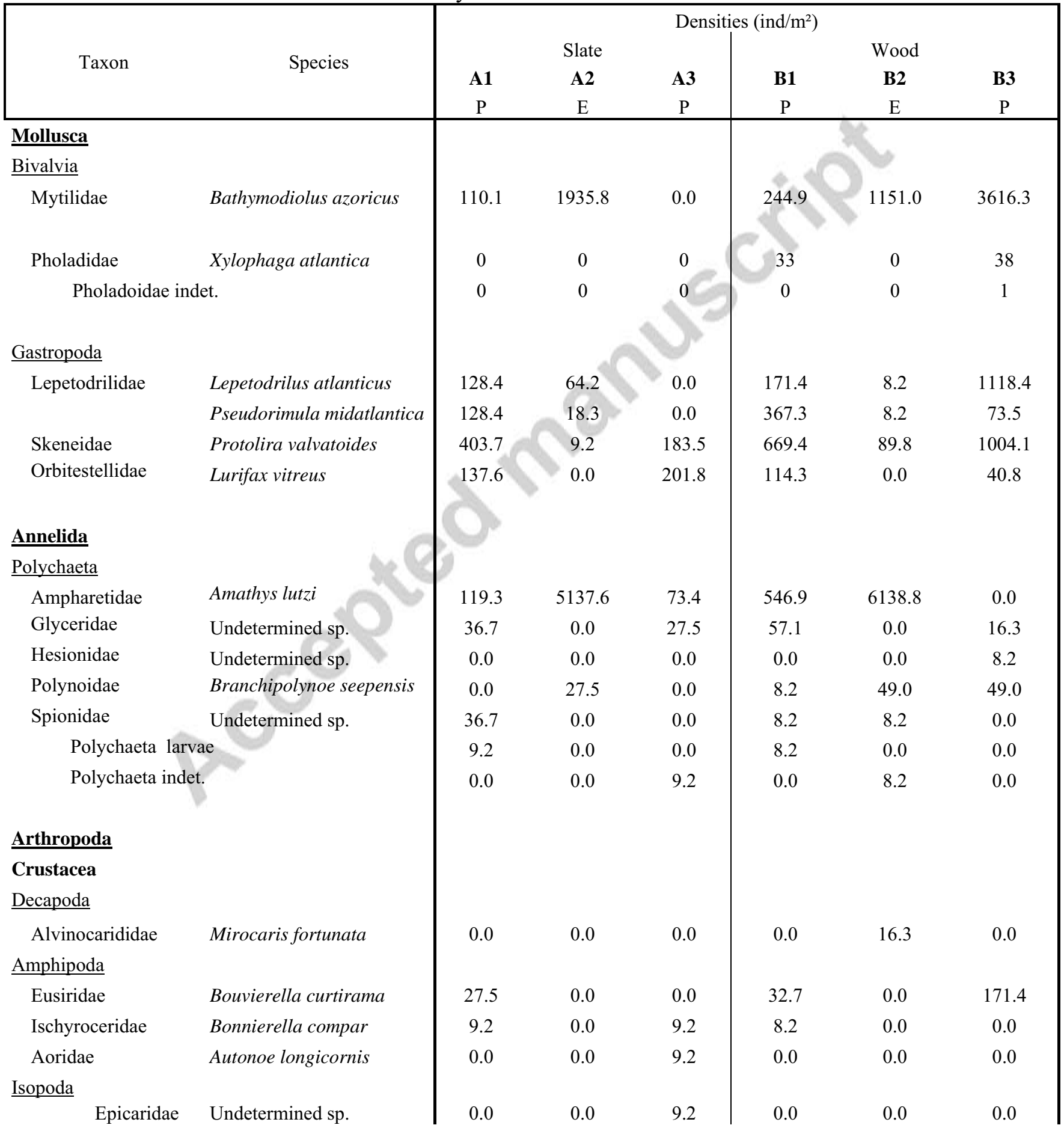


Tanaidacea

Nototanaidae

Obesutanais sigridi

688.1

0.0

228.6

0.0

0.0

Cirripedia

Undetermined sp.

9.2

0.0

0.0

0.0

0.0

Copepoda

Cyclopoida

Cyclopinidae

Harpacticoida

Ameiridae

Ancorabolidae

Undetermined spp.

Lobopleura cf. expansa

Ectinosomatidae

Undetermined spp.

Laophontidae

Bathylaophonte cf. azorica

Miraciidae

Amphiascus spp.

Pseudotachidiidae

Donsiellinae

Donsiella cf. bathyalis

Xylora cf. bathyalis

Tegastidae

Smacigastes micheli

Tisbidae

Tisbe spp.

Harpacticoida copepodid indet.

Harpacticoida nauplii

Harpacticoida indet.

Siphonostomatoida

Dirivultidae

Aphotopontius atlanteus

\section{Chelicerata}

Acarina

Halacaridae

Halacarellus auzendei

\section{Nematoda}

Adenophora class Undetermined sp.

Chromadorida

Chromadoridae

Chromadorita

Cyatholaimidae

Paracanthonchus

Paracyatholaimus

$\underline{\text { Desmodorida }}$

Draconematidae

Cephalochaetosoma

Dinetia

Desmodoridae

Desmodora

Epsilonematidae

Epsilonema

Microlaimidae

Microlaimus

Monhysterida

Monhysteridae

Halomonhystera

Xyalidae

Cobbia

Total density (no wood-boring)

Theristus

Taxonomic richness (no larvae or nauplii)

Rarefaction $(\mathbf{n}=\mathbf{1 0 0})$

Colonisation index (no wood-boring)

(average ind $/ \mathrm{m}^{2} /$ day) 
Table 2. Results of image analyses of the habitat surrounding the different substrata in 2006 and 2008 (deployment and recovery). A surface area of $1 \mathrm{~m}^{2}$ around the deployment localities was analysed. Ind $/ \mathrm{m}^{2}=$ number of individuals per $\mathrm{m}^{2} .{ }^{*}$ Panel A3 moved from its original position to about $30 \mathrm{~cm}$ further.

\begin{tabular}{|c|c|c|c|c|c|c|}
\hline & \multicolumn{2}{|c|}{ A1B1 } & \multicolumn{2}{|c|}{ A2B2 } & \multicolumn{2}{|c|}{ A3B3 } \\
\hline & 2006 & 2008 & 2006 & 2008 & 2006 & 2008 \\
\hline Engineering species $\left(\mathrm{ind} / \mathrm{m}^{2}\right.$ ) & & & & & & \\
\hline Bathymodiolus azoricus & 66 & 53 & 1001 & 941 & 435 & 435 \\
\hline Dead B. azoricus shells & 10 & 31 & 0 & 0 & $\begin{array}{l}\text { too shattered } \\
\text { to estimate } \\
\text { densities }\end{array}$ & $\begin{array}{c}\text { too shattered } \\
\text { to estimate } \\
\text { densities }\end{array}$ \\
\hline Percentage of coverage & & & & & & \\
\hline Microbial cover & $19.5 \%$ & $3.2 \%$ & $32.5 \%$ & $35.7 \%$ & $32 \%$ & $14.4 \%$ \\
\hline Mussel cover & $4.2 \%$ & $4.6 \%$ & $59.9 \%$ & $65.7 \%$ & $19.7 \%$ & $16.8 \%$ \\
\hline Mobile organisms ( ind $/ \mathbf{m}^{2}$ ) & & & & & & \\
\hline Mirocaris fortunata & 12 & 10 & 51 & 30 & 16 & 11 \\
\hline Chorocaris chacei & 0 & 0 & 1 & 0 & 0 & 0 \\
\hline Segonzacia mesatlantica & 2 & 0 & 4 & 4 & 2 & 2 \\
\hline Pycnogonida & 1 & 0 & 0 & 0 & 0 & 0 \\
\hline Polynoid polychaetes & 0 & 0 & 0 & 0 & 0 & 1 \\
\hline Fluid exits and description & $\begin{array}{c}\text { Yes - } \\
\text { fluid exit } \\
\text { partially } \\
\text { covered } \\
\text { by A1 }\end{array}$ & $\begin{array}{l}\text { Yes - but } \\
\text { fluid exit } \\
\text { covered by } \\
\text { A1 no } \\
\text { longer } \\
\text { active }\end{array}$ & $\begin{array}{c}\text { Yes - at } \\
\text { least } 3 \\
\text { sources } \\
\text { of visible } \\
\text { activity }\end{array}$ & $\begin{array}{c}\text { Yes - at } \\
\text { least } 3 \\
\text { sources of } \\
\text { visible } \\
\text { activity }\end{array}$ & $\begin{array}{c}\text { Yes - } \\
\text { shimmering } \\
\text { water in } \\
\text { cracks and } \\
\text { under ledges } \\
\text { behind A3 }\end{array}$ & $\begin{array}{c}\text { B3: Yes - } \\
\text { shimmering } \\
\text { water in cracks } \\
\text { and under } \\
\text { ledges } \\
\text { A3: None* }\end{array}$ \\
\hline Min. distance from fluid exit to panel A & $7 \mathrm{~cm}$ & $14 \mathrm{~cm}$ & $12 \mathrm{~cm}$ & $12 \mathrm{~cm}$ & $1 \mathrm{~cm}$ & $19 \mathrm{~cm}$ \\
\hline Min. distance from fluid exit to panel B & $28 \mathrm{~cm}$ & $33 \mathrm{~cm}$ & $18 \mathrm{~cm}$ & $19 \mathrm{~cm}$ & $11 \mathrm{~cm}$ & $10 \mathrm{~cm}$ \\
\hline Imagery analysed (time available) & $12 \min 30$ & $3 \min 48$ & $8 \min 09$ & $5 \min 04$ & $6 \min 35$ & $5 \min 11$ \\
\hline
\end{tabular}

\section{FIGURES}

Fig. 1. Location of the Lucky Strike vent field on the Mid-Atlantic Ridge (MAR) at $37^{\circ} 17.59 \mathrm{~N}, 32^{\circ} 169 \mathrm{~W}$. The inset shows the hydrothermal vent field with the location of several active sulphide edifices around a central lava lake, including the Eiffel Tower edifice in the south-east.

Fig. 2. Location and depth of the sites at the Eiffel Tower edifice (MAR) where different substrata were deployed in 2006 and recovered in 2008. On each locality a panel of slate (A) and wood (B), each equipped with a NKE temperature probe, were deployed. Note the change in location of panel A3 in 2008.

Fig. 3. Boxplots of recorded temperature values averaged per $24 \mathrm{hrs}$. No temperature data are available for Substratum A3, due to a probe failure. (a) Significant differences were 
noticeable in the temperature data between all panels, albeit to different extents. Highest minimum, maximum and mean temperature values were observed for A2 and B2, while largest standard-deviations and temperature ranges were found in A2, B3 and B2 respectively. (b) Significant temperature differences were found between the localities. (c) Overall, no distinct significant differences were observed between the substratum type (slate (A) vs. wood (B)). B3 was not included in this boxplot due to the absence of A3 temperature data.

Fig. 4. Principal component analysis (PCA) of Hellinger transformed faunal abundances with mixed taxonomic levels from slate and wood panels deployed on or in the vicinity of the Eiffel Tower edifice (MAR). The first two axes represent $65.5 \%$ of the total variance. The enlargement box clarifies the main species cluster, and includes genus and family names as well as abbreviations to enhance readability. (Harp=Harpacticoida, Poly=Polychaeta)

Fig. 5. Canonical redundancy analysis (RDA) performed on the matrix of faunal abundances with mixed taxonomic levels sampled from slate and wood panels deployed on or in the vicinity of the Eiffel Tower edifice (MAR) and the matrix of environmental factors (here mean temperature and standard deviation). The two first axes represent $80.77 \%$ of the total variance and the first axis is significant (as is the entire RDA). Environmental variables withheld after forward selection were Mean_T $=$ mean temperature and Stand_Dev $=$ standard deviation on temperature values. The enlargement box clarifies the main species cluster, and includes genus and family names as well as abbreviations to enhance readability.

(Harp=Harpacticoida, Poly=Polychaeta)

Highlights for review

- Colonisation substrata within close proximity of hydrothermal fluid flow

- Comparison of colonisation of wood and slate substrata at vents

- Community analyses of maco- and meiofaunal composition

- Influence of temperature and hydrothermal activity on colonists 


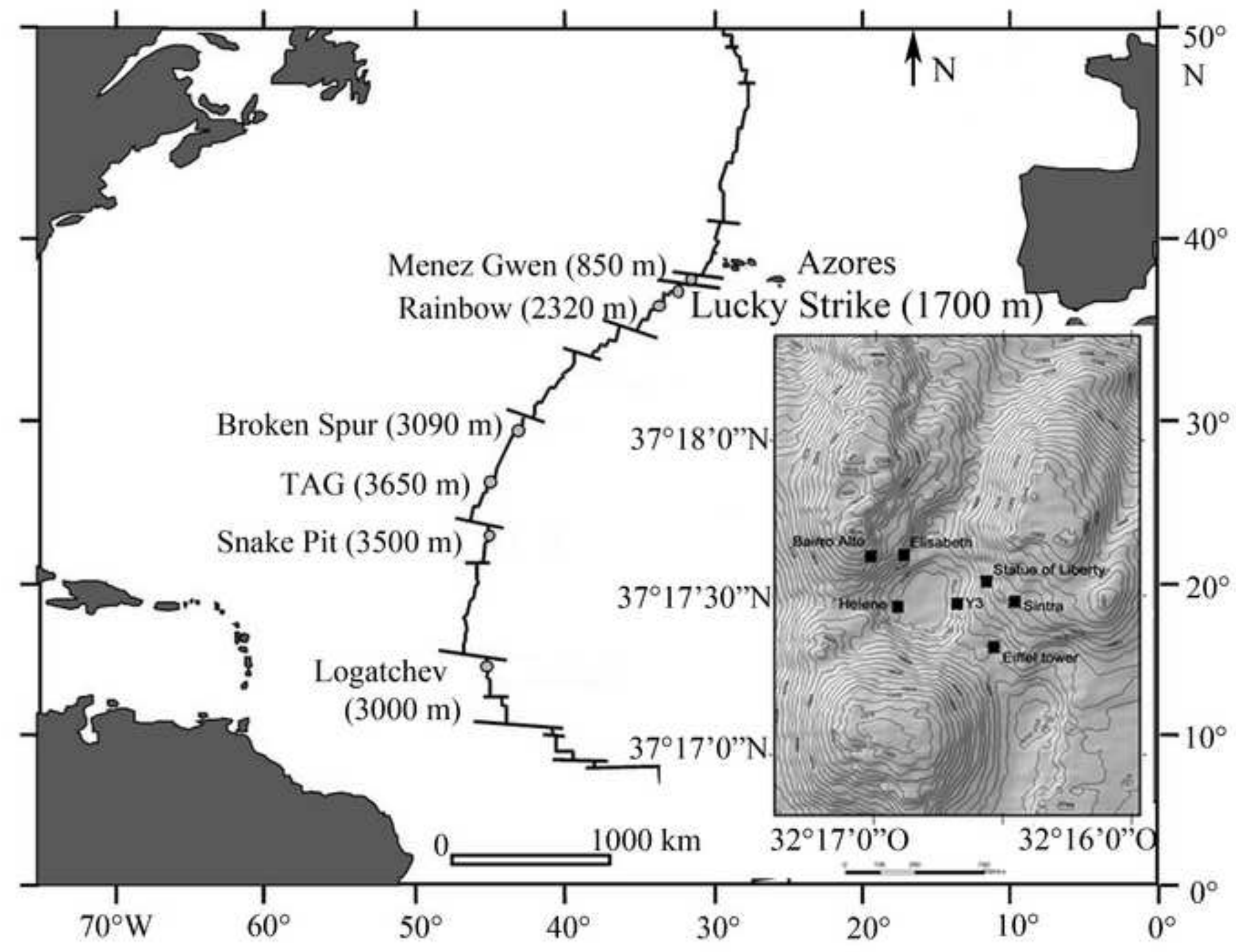



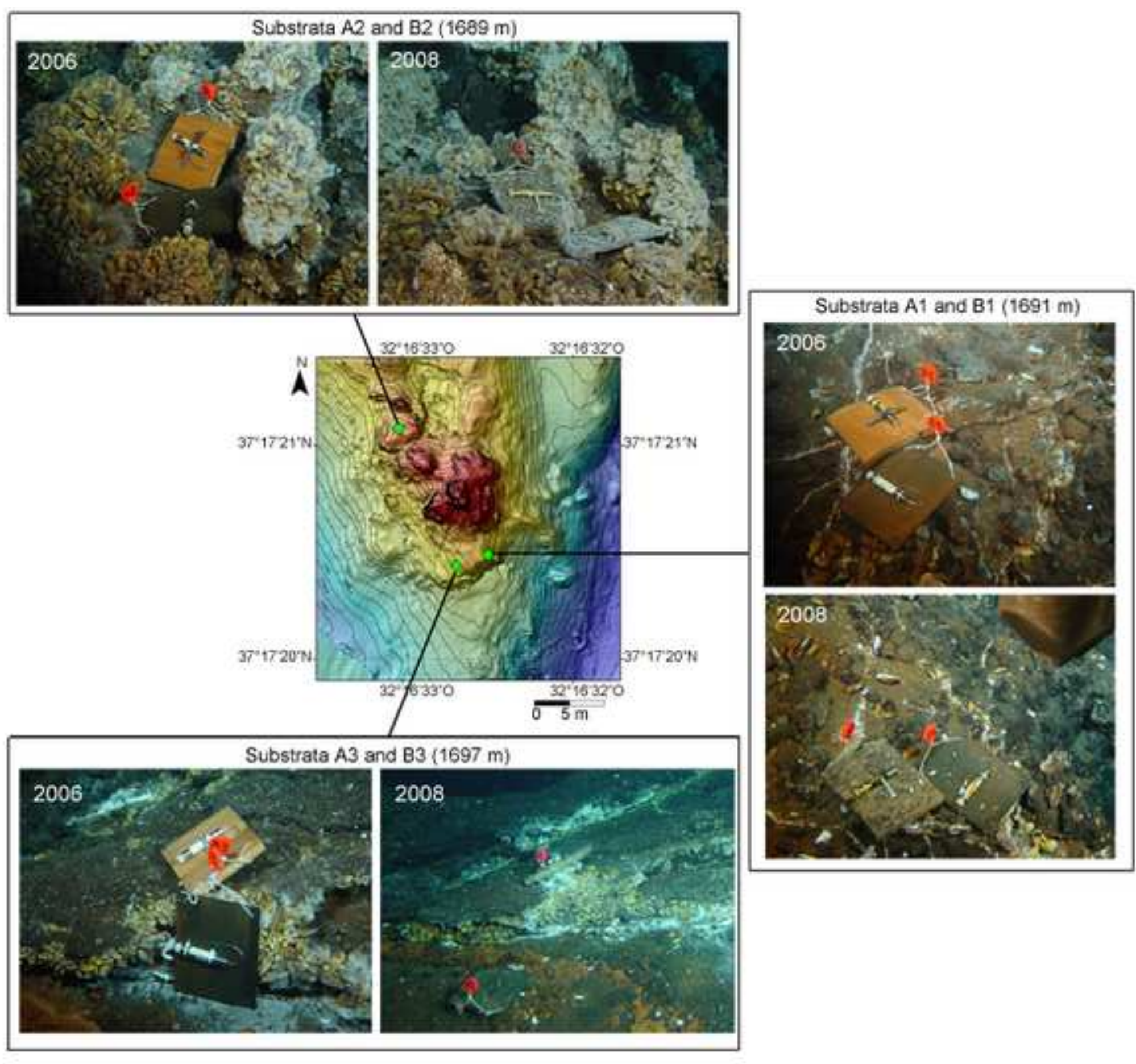

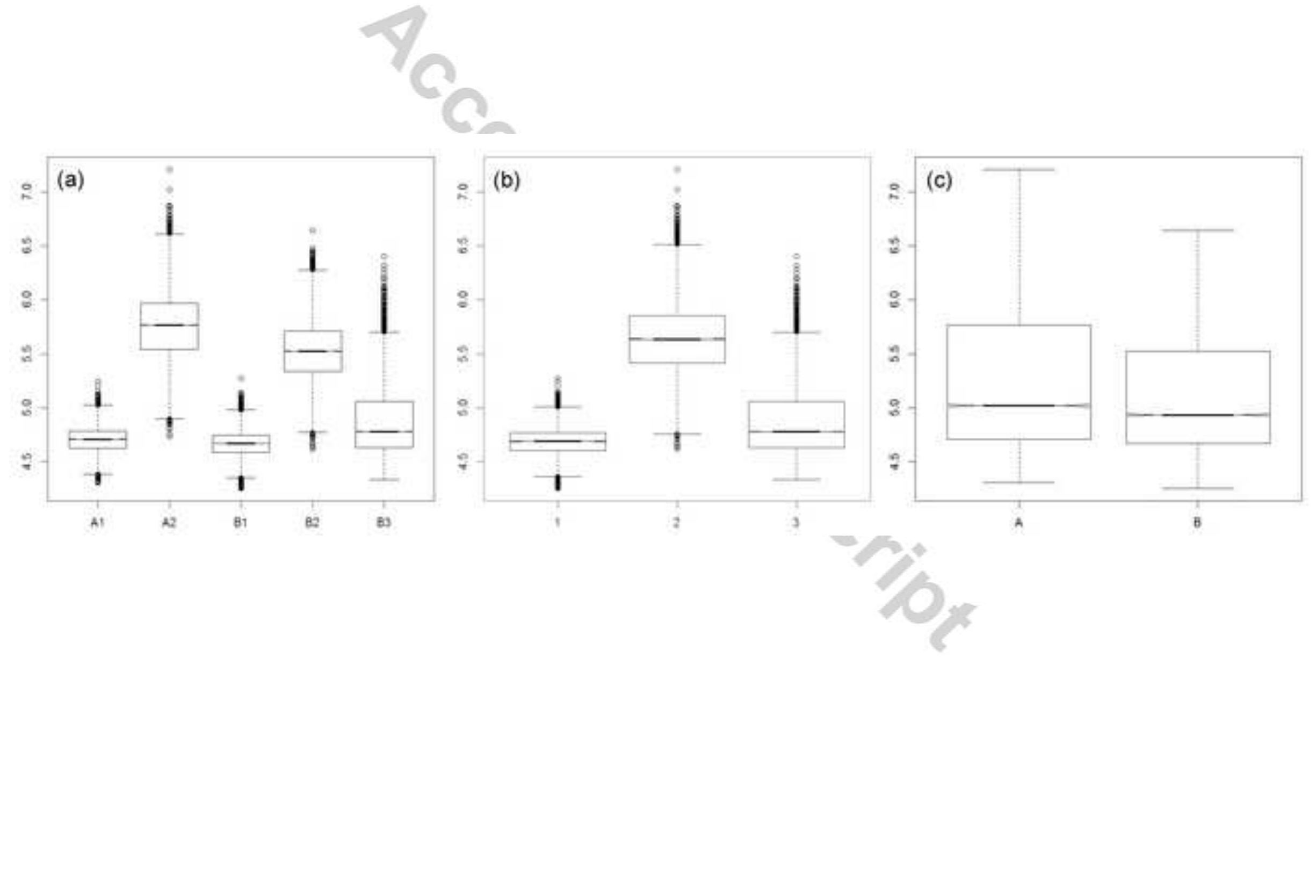

-

- 


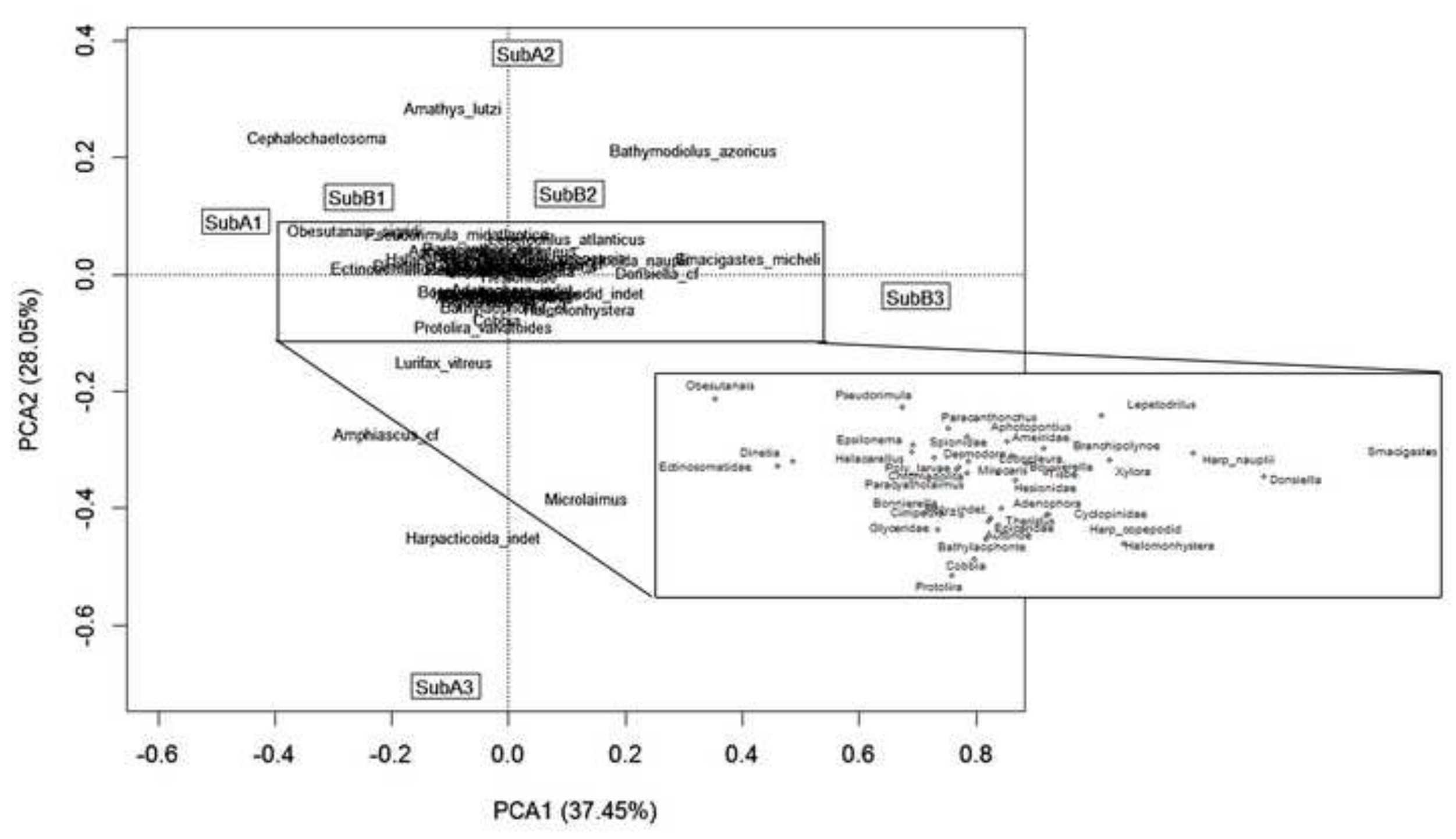




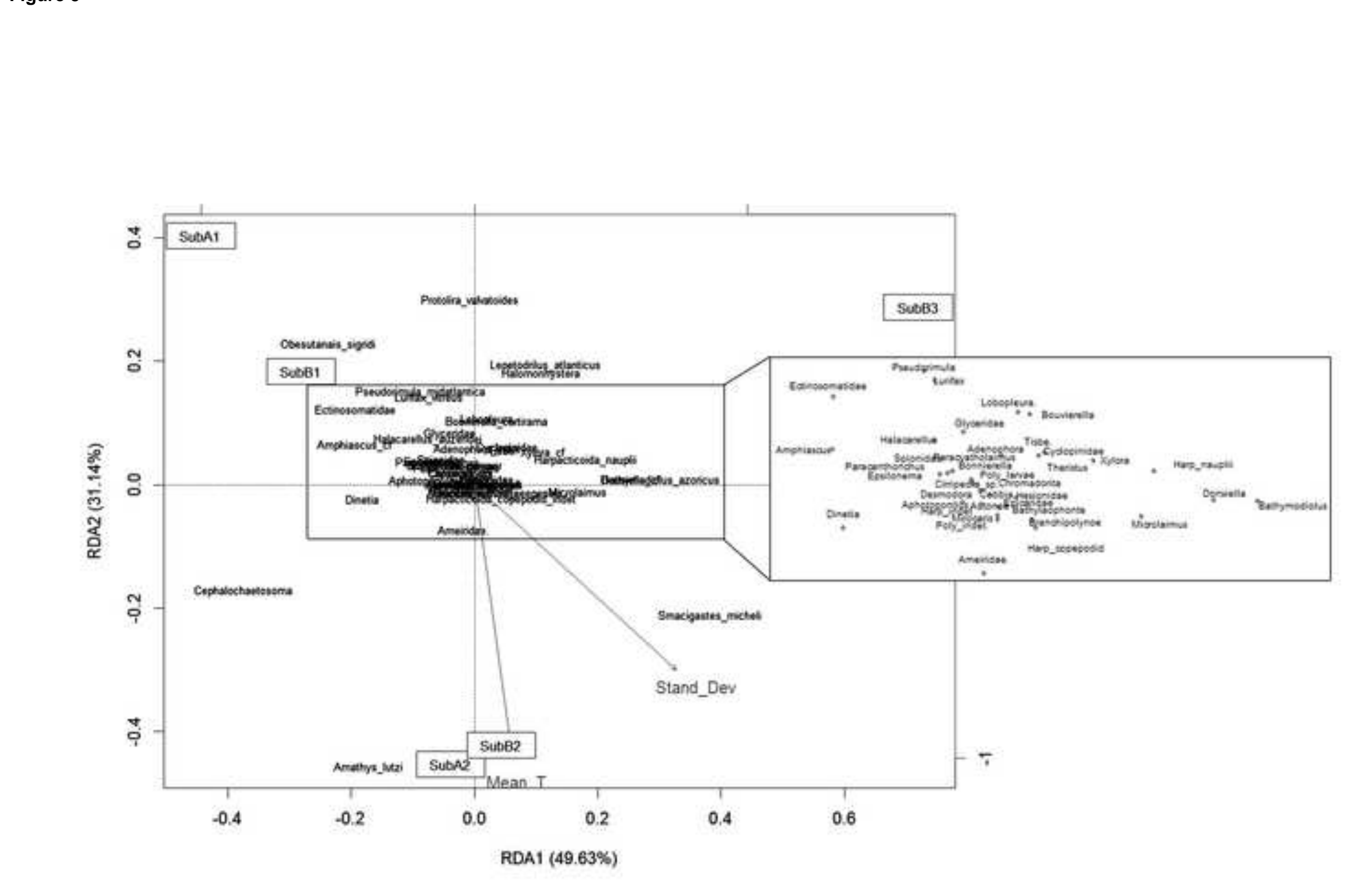

Figure 5

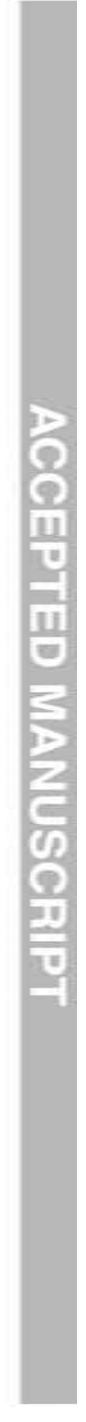

